UDC 37.07(336.14)(332.146)

DOI https://doi.org/10.32840/1813-3401-2019-3-32

N. A. Yasynska

Doctor of Economic Sciences, Associate of Professor, Professor of the Department of Finance, Accounting and Taxation, Donetsk State University of Management

T. M. Radchenko

Chief Specialist of the Planning section of Finance, Department of Labor and the social protection of population,

Mykolaiv city council

\title{
THE DOMINANTS OF FINANCIAL ENLIGHTENMENT OF UKRAINIANS IN THE CONDITIONS OF DECENTRALIZATION (THE EXPERIENCE OF POLAND AND GERMANY)
}

In condition of systemic reforms which take place in Ukraine, changes of access to financing of educational process, revealing of the current dominant of financial education of Ukrainians and the level of their financial literacy and culture became needful. Their research is actual and one that should be introduced into the state monitoring system for the correction of the dominant components of the educational process and labor market demands. Taking into account foreign experience (Poland and Germany), the specificity of educational reforms in the conditions of internal competition between administrative-territorial units (lands, provinces, communities) on a number of social and financial indicators is complicated. The paper assesses current functioning condition of financial enlightenment of ukrainians in the conditions in Ukraine according to the results of the first stage of financial decentralization. So, there are the Human Development Index in Ukraine, Germany, Poland in 1990-2015, the indicators of continuity of education in particular countries of the world and comparative table of the competitive advantages of particular countries in the realization of the "Industry 4.0" in it. The article presents the stages of development of the education system in conditions of decentralization in Poland, Germany and Ukraine. It is argued that in the condition of reforming of educational system and decentralization in Ukraine, on the background of technological modernization of the world industry, it is appropriate to modernize all areas of educational training. Along with this, they must have a high level of financial literacy. At the same time, all subjects of the educational process should be oriented on current labor market demands, competitive advantages and should maximize their own financial inflows from the provision (or receipt) of educational services. The article proposes to solve the problems of increasing the financial education of citizens in the conditions of decentralization by means of fundamentalization of the general trend in the system of education and the use of the tools, mechanisms and sources mentioned in the article.

Key words: finance, education, culture, experience, distribution, competence, human development index.

Problem statement. There is a belief in today's educational practice, that the main task and purpose of education is to transfer to the recipient intellectual, scientific and moral knowledge and also the rules of culture. In this case the main method of education is the direct studying well-known, complete, integral information and rules. When preschool, school and out-of-school educations have minor degree of diversification of curricula, methods and accesses, in that time university education, in condition of multifaceted human activities, covers all spheres of social life. The most impress- ible place of traditional university education is that the direct subject of study in it are already allocated and previously authoritatively structured subjects of the study cycle, which are behind certain, isolated and grouped by external means of ability cultural objects. And if we tell about the training of specialists in history, art, culture, mathematics, there is a certain time lag of conceptual change that lasts for decades. At the same time the modern training curricula for finance specialists are static because of the high dynamics development of financial market. They do not take into account 
financial and economic changes and the diachronic perspective of research in financial theory and practice.

Analysis of research and problem statement. The subject area of research is directly related to theoretical and empirical research of the issues of financial conversance of the population of Ukraine. These questions are devoted to the papers of T. Kizyma, M. Ovchinnikov, S. Yuriy and others. As indicated and proved by the research $[1$, p. 4], modern Ukrainian users of financial service have only basic knowledge and skills and mainly use the simplest financial market services. The group of researchers of report avers that raising awareness among citizens should take place by public expense. However, the system of educational institutions of Ukraine, gradually incorporating the ideological component of the priority of decentralization in the state, acquires the status of autonomy and diversifies sources of funding through local budgets, grant financing, endowment and sponsorship contributions [2].

Only during the noon of industrial revolutions, the development of the economy is mainly based on scientific achievements, and not on just successful inventions. Their results change the sociological system of human being. At the beginning of the XXI century, entered the fourth industrial revolution, European countries have not solved the problem of competitiveness of domestic industry. It also was marked the education system. Modern European system of education, in accordance, of studying as before couldn't manage with the giving of due skills of employment and do not work adequately with business or employers to bring studying experiences to the reality of the working environment. As pointed out in $[3 ; 4 ; 5 ; 6]$, humankind stands near the turns of revolution, which radically will change our world. According to J. Halllevale, R. Patname and F. Fukuyama, education is a means of cumulation of social capital $[7 ; 8 ; 9]$.

The purpose of the article is to improve the problem of dominants of financial enlightenment of Ukrainians in the conditions of decentralization and to make recommendations for the way of its execution.

Research results. Receiving by Ukrainians the financial education in condition of decentralization carries out at the levels of schools, lyceums, colleges and universities. If schools and lyceums, in whole or partly (depending on the form of ownership and funding sources) participate in the implementation of the program for the decen- tralization of education, the colleges switched to financing local budgets of district and cities of regional significance in 2018, then universities have become financial autonomous of institutions of higher education since 2013. According to the results of decentralization of power and reformation of local self-government as of March 12, 2019 [10], out of 1355 territorial communities, only 93 entities were concluded 360 agreements of municipal cooperation. Of the total number of concluded contracts, 82 units are committed to education, health care and social security. Such areas as Zakarpattya, Lugansk, Mykolayiv, Odesa, Kharkiv, Kherson, Khmelnytsky and Kyiv did not conclude any of such contracts in this area of the statistical sample. Accordingly, even the primary level of financial education does not cover the process of decentralization. The claim of society to modern universities is that students in it deal with practically ready forms of culture, with a standard set of disciplines, even in the format of a block of free choice of students. Accordingly, a student-financier, prepared according to a format curriculum, almost never has experience of working on the borders established by the financial market and regulatory legal acts of order. German higher education institutions consider the concept of diversity management (including disciplines in the curriculum) as an element of strategic planning and development of university [10]. Management of the variety of proposals by the blocks of the curriculum for each area of training at the universities of Germany has three groups of concepts: the first group - management focuses on managerial aspects, at the formation of a set of conditions that ensure the integration of all students into heterogeneous environments of the university within the framework of the participative management; the second group - accent pedagogical management of the educational process in institutions of higher education (or IHE); the third group focuses on providing pedagogical support and consultancy for students belonging to different social groups at the beginning of education. The modern graduate of the national university practically is not ready to work in the schedule of generating new cultural norms and forms, including the new financial relations. He is practically prepared to exit in the available being culture, strictly following to the acquired professional norms and scarcely to venture outrun its limits. Along with this to the teachers of the national universities are imposed the following requirements [11]: authority 
in the field of scientific research; reputation among employers; index of citation.

However, there is no understanding of the free choice by students this or that teacher, which they see as a lecturer in the relevant financial discipline. Such access instigates the invention other factors that will react at the rating of a teacher who works for an educational professional training program for a financier - this is the ratio of the teaching staff to the number of students, the share of foreign students who listen to the course with the stated teacher; the share of foreign teachers who co-operate with their national colleagues, etc.

The task of the university in the present situation can be denoted as the formation an experience of working by student-financier on the boundaries of order but in a legitimate area. This provides change the perspective of vision of the university, and in particular - the turning in the organization of the educational process in the modern university. The educational process should be organized in a different way and based on the current value-based basis of the financial market. Necessary change in value systems is from the value of knowledge to the value of ignorance. To do this, we must turn to the essence of the basis of the educational process of the XXI century and the stages of the evolution of higher education in Ukraine. For example, having received a visa-free travel, modern Ukrainian youth has more priorities in obtaining education abroad for a number of subjective-objective reasons [12]. In other words, Ukrainians support and develop the tendency of Europeanization of higher education, including financial. K. de Vita and J. Verhoven distinguish three periods in the development of the trends of Europeanization of higher education in the second half of the twentieth century [13; 14]:

- the first period (1957-1982) (mutual recognition of diplomas, the formation of the idea of the modeling of a European university, the cooperation of the second and third stages of secondary education with higher, the formation of a European center for the development of education, the formation of unlimited state borders of the higher education institutions, recognition of diplomas, general education programs etc.);

- second period (1983-1992) (correction of goals, tasks and problems of cooperation of higher education in the European Union space, definition of the legal side of this process);

- the third period (since 1993) (promotion of knowledge production, education and economy approximation, strengthening of the role of education as a second person's chance, assimilation of graduates not less than three European languages, approval of equal value of investments in economy and education).

The Experience of Poland and Germany. Laying in the first period basis for the development of higher education expands the boundaries of the educational process. According to the opinion of the Polish researcher M. Kveik, the consequence of globalization is the depreciation of national projects, and among them the university (nation-oriented and state-based institutions) [15]. However, exactly modern Poland demonstrates the opposite, but quite successful practice in higher education, including financial. The Polish model of the decentralization of education distinguishes following models of education management: combined, decentralization, decentralization and delegation. The choice of one or another model of education depends on the model of the division of responsibilities between different levels of management and is associated with various mechanisms of funding of educational institutions [16, p. 2-3]. M. Herbst and Y. Gerchinsky consider the following stages of decentralization of education management (in general and gradually by the level of education received by youth) in Poland [16, c. 6-7]:

- 1990 (kindergarten management) - was restored to the self-government community and territorial self-government, were held the first elections to self-government

- 1993 (management of primary schools) was transferred to community self-government;

- 1996 (primary school management; management of schools from the upper level) - was transferred to self-governance community, also was introduced a two-steps education financing system; a part of the educational subvention was established in the framework of the general subvention that was passed by the government to self-government units; was transferred to the self-government of the big cities on a voluntary basis of the pilot program, also were realized pilot projects for other future tasks of the counties (health care, etc.);

- 1999 (management of gymnasium, of higher schools from gymnasium, of regional educational institutions) - was transferred to self-governance community also gymnasium was introduced as a new level of education and profiled lyceum as a new professional school; was transferred to the self-government of the counties, also was created 
a new level of territorial self-government - districts; were transferred to the voivodship's self-government, also the self-government in voivodships was created and given to it the selected tasks of a regional character.

Such approach to the educational process (orientation to the territorial community) requires from the institutions of education (primarily universities) to constantly monitor labor market demands. Accordingly, the education system is dynamic and has stable relationships and relationships with employers. Polish higher education establishments are divided in university and non-university degrees [17]. University-type IHE include institutions of education, in which at least one organizational unit (faculty, etc.) is authorized to assign a doctorate's grade. They prepare by the bachelor's, master's and doctoral programs. Non-university type training institutions include educational institutions, which provide a service for the training of specialists in bachelor and magistracy. To this type of institution are IHE, which are still called higher vocational education schools and prepare only bachelors. Financial education can be acquired in educational institutions of both types. Nearly $70 \%$ of state-owned IHE are university-type institutes, while another $30 \%$ are non-university.

Germany has a decentralized system of education, passed on to land, and has two types of IHEs - classical universities and higher professional schools that have "narrow» training on the profile of functioning [18]. Professional standards in Germany are widely used in close connection with educational professions. In the dual education system in Germany, professional standards are combined with educational and qualification standards [19]. The general system of higher education in Germany differs from other countries. Among these differences, in particular, are:

- lack of fees as a tool of financing and management of higher education;

- institutions of higher education are selected only a limited number of students.

Where the number of students in high demand subjects is too large, candidates are assigned a central office between different universities [20]. Profile IHE are consider such benefits of receiving of financial education in Germany [21]:

- adaptive study of the German economy as the "strongest" economy in Europe (21\% of the Eurozone GDP), in theory and practice;

- Germany is a regional leader in investment research and development. Each year, the country spends more than 80 billion euros on assistance to about 800 research-financed institutions;

- a single market and a favorable geographic location for economic operations;

- generation of innovations and economic freedom. Of the $28 \mathrm{EU}$ countries, more than $40 \%$ of all patents belong to Germany.

Agreeing with the conclusions conducted by L. Yurchuk a study on the effectiveness of horizontal and vertical distribution of powers and functions in relation to education in Ukraine and that "Decentralization of education management in Ukraine should take place taking into account regional features, interests of territorial communities, social stratum by the choosing management models, reforming the content of education, ways of its organization and financial support" [22], we note that the basic processes of education of the XXI century include research and analytics. The task of designing of a modern university as a place of cultural generation should include two aspects: socio-cultural analysis (included as a compulsory moment in the curriculum, studying and practicing various forms of rationality, organizing those or other modes of activity in the socio-cultural space) and practice of will (people act in these systems, modifying to known limits the rules of the game). In this case, three processes which must be adapted in the educational process of a modern university are crucial: free event; constitutionalisation; problematization-deconstruction.

For it is important not the structural significance, but the representative integrity of the cultural experience. Awareness of the importance of financial education is gaining momentum among financial policy makers around the world. The OECD and its International Financial Information Network (INFE) provides a unique policy platform for governments to exchange views and experiences on this issue [1]. Financial education, based on the Recommendations on the Principles and Appropriate Practice of Financial Education of the OECD, is "a process by which financial consumers / investors improve their understanding of financial products, concepts and risks and, through information, instructions and / or objective recommendations, develop skills and confidence to become more aware of financial risks and opportunities to make informed choices and to know when to seek help and take other effective measures to improve their financial well-being" [23, 24]. Financial education thus goes beyond the provision of financial information and advice. It should be provided fairly and objec- 
tively on the basis of the principle of effectiveness. The current requirements for financial education are as follows:

- financial education and programs should focus on priority issues that, depending on national conditions, may include important aspects of financial planning, such as savings, private debt management and insurance;

- knowledge of elementary financial mathematics and economics;

- awareness of the financial future of pensioners regarding the need to assess the financial adequacy of their current public or private pension systems and take appropriate measures (if necessary);

- financial education should be invested in the regulatory and administrative framework and considered as an instrument for promoting economic growth, strengthening confidence and stability, along with the regulation of financial institutions and the protection of consumer rights;

- promote the development of regulatory actions in the financial market for the protection of consumers' rights, depositors, etc.;

- the role of financial institutions in financial education should be encouraged and become part of their proper management of their clients. Accountability and accountability of financial institutions should be encouraged not only in providing information and advice on financial matters, but also in promoting financial awareness of clients, especially in the case of long-term liabilities and liabilities that constitute a significant proportion of current and future earnings;

- financial education programs must meet the needs and levels of financial literacy of their target audience, as well as predict how the target audience wants to receive financial information;

- financial education should be considered as a long time and continuous process, in particular, in order to take into account the increased complexity of the markets, the changing needs of different stages of life, and increasingly complex fi- nancial information;

- financial education should start at school. People should be aware of financial issues as early as possible;

- the issue of obtaining financial education within the framework of state social assistance programs should be considered;

- appropriate specialized structures (state level and level of territorial communities) should be encouraged through public and private initiatives (national funding sources) to develop financial education;

- broad information (internet) support to provide appropriate free financial information services to the public;

- international cooperation on financial education;

- diversification within the legislative boundaries sources of financing of territorial units by results of decentralization (own income, general and targeted subsidies, subventions, funds of international organizations, European funds or the EU).

In this case, the role of financial institutions in the financial world is increasing, as the requirements for the corresponding education increase. Financial education, like any other product, has to be successfully sold on the educational market of services. The quality of financial education is determined by the financial literacy of the population. According to S. Yuriy and T. Kizyma, "financial literacy of the population is a set of attitudes, knowledge and skills of citizens on the effective management of personal finances and the ability to apply them competently in the process of making financial decisions" [25, p. 19]. Under financial literacy M. Ovchinnikovunderstands the resultoftheprocess of financial education or "... a set of two elements:

1) ownership by individuals of information about existing financial products and their producers / sellers, as well as existing channels for obtaining information and consulting services;

2) the ability of financial service consumers to use available information in the decision-making

Table 1

Human Development Index (HDI) in Ukraine, Germany, Poland in 1990-2015 (extract)

\begin{tabular}{|l|c|c|c|c|c|c|c|c|}
\hline \multicolumn{1}{|c|}{ Country } & $\begin{array}{l}\text { HDI, } \\
\mathbf{1 9 9 0}\end{array}$ & $\begin{array}{c}\text { HDI, } \\
\mathbf{2 0 0 0}\end{array}$ & $\begin{array}{c}\text { HDI, } \\
\mathbf{2 0 1 0}\end{array}$ & $\begin{array}{c}\text { HDI, } \\
\mathbf{2 0 1 1}\end{array}$ & $\begin{array}{c}\text { HDI, } \\
\mathbf{2 0 1 2}\end{array}$ & $\begin{array}{c}\text { HDI, } \\
\mathbf{2 0 1 3}\end{array}$ & $\begin{array}{c}\text { HDI, } \\
\mathbf{2 0 1 4}\end{array}$ & $\begin{array}{c}\text { HDI, } \\
\mathbf{2 0 1 5}\end{array}$ \\
\hline \multicolumn{8}{|c|}{ Countries with very high levels of HDI } \\
\hline Germany & 0,801 & 0,860 & 0,912 & 0,916 & 0,919 & 0,920 & 0,924 & 0,926 \\
\hline Poland & 0,712 & 0,784 & 0,829 & 0,834 & 0,838 & 0,850 & 0,852 & 0,855 \\
\hline \multicolumn{8}{|c|}{ Countries with high levels of HDI } \\
\hline Ukraine & 0,706 & 0,673 & 0,734 & 0,739 & 0,744 & 0,746 & 0,748 & 0,743 \\
\hline
\end{tabular}


process: when conducting special calculations, assessing risk, comparing the comparative advantages and disadvantages of one or another financial service" [26].

This indicator directly affects the level of socio-economic development. And it, among other things, has an international level of monitoring.

There are three important developmental factors in these countries: proactive "state of development"; use of opportunities of global markets; resolute introduction of innovations. All this allows for high HDI. After all, the index measures the achievements of the country in terms of health, education and the actual income of its citizens, in three main areas:

- health and longevity, measured by the indicator of the expected life expectancy at birth;

- access to education measured by adult literacy and gross education coverage;

- a decent standard of living measured by the value of the gross domestic product per capita, based on purchasing power parity. These indicators are directly related to the success of the implementation of financial policies, both in the country as a whole and in its regions, as well as in the educational process. This affects the sources and volumes of funding for higher education institutions.

Assessing the needs of the population in financial literacy as one of the main elements of national financial policy should be carried out regularly. It can be the basis for indicator comparison of the level of development of a particular territorial community. Estimates can be obtained from sources such as consumer surveys and market research, opinion polls, consumer complaints, financial market reviews, financial and economic indicators, or other advisory processes. Evaluations should provide a more accurate definition of the national strategy of financial education and financial literacy of the population of the country or community, the main priorities and short-term and long-term goals. For this future, not only financial education, but also the financial autonomy of territorial communities.

Financial education programs should include elements of different types of goals:

- the first kind of program provides consumers with only information. Its purpose is to raise awareness of as many people as possible;

- other programs are designed to increase knowledge and skills. In these cases, the tests should be distributed before and after the program to determine the quality indicators of the learning outcomes. Further research can be used to study the conservation of knowledge or skills;

- the third type of program is designed to develop a new behavior or change existing behavior. Evaluators should take into account the length of the monitoring and evaluation processes to determine the degree of behavior change.

The basis of the problem of increasing the financial education of Ukrainians in the context of decentralization lies in the nature of financial services (products) and markets in which these services (products) are rotated, and factors that create increased demands on financial literacy of market participants. The reasons for the existence of these factors are:

1) financial products are consumed relatively rarely, which limits the formation of experience of their consumption;

2) financial products cannot be tested for quality at the time of their acquisition, resulting in a lot of opportunities for unscrupulous conduct by the seller;

3) costs of audit the authenticity of the parties' commitments are cost.

Financial education programs should include elements of different types of goals:

- the first kind of program provides consumers with only information. Its purpose is to raise awareness of as many people as possible. In such cases, the monitoring data provides sufficient evidence of the program's achievement of its goals;

- other programs are designed to increase knowledge and skills. In these cases, tests must be distributed before and after the program to determine the quality of the results of learning outcomes. Further research can be used to study the conservation of knowledge or skills;

- the third type of program is designed to develop a new behavior or change existing behavior.

Evaluators should take into account the length of the monitoring and evaluation processes to determine the degree of behavior change.

The Experience of Ukraine. For Ukrainian citizens and recipients of financial education, the main problem, on the one hand, and the factors of obtaining the basic knowledge and skills necessary to achieve the financial safety of material welfare, on the other hand, are:

- formation of limited experience of using financial products in the conditions of limited access to the insufficiently developed financial market of the country;

- not the development of the infrastructure of self and institutional control over the quality and 
$\frac{0}{2}$

\begin{tabular}{|c|c|c|c|c|c|c|c|c|c|c|c|c|}
\hline $\begin{array}{l}8 \\
8 \\
0\end{array}$ & 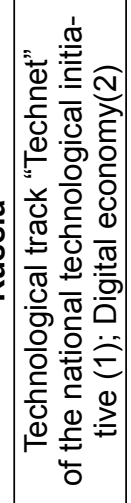 & 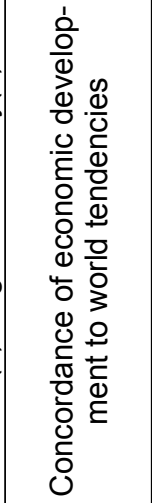 & 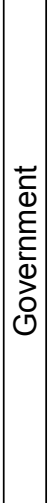 & 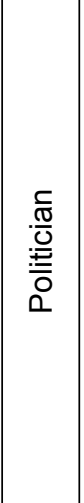 & 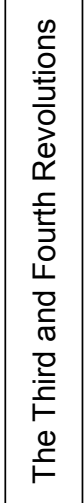 & 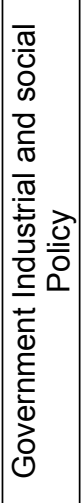 & 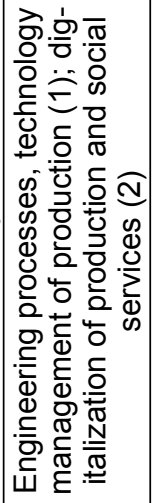 & 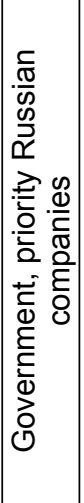 & 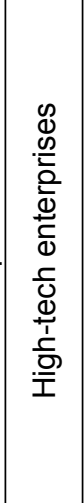 & 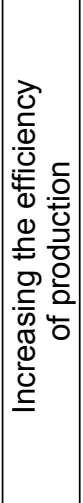 & 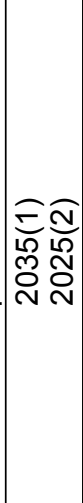 & 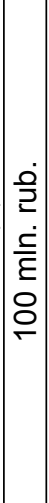 \\
\hline$\frac{s}{c}$ & 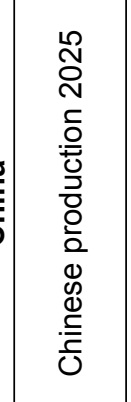 & 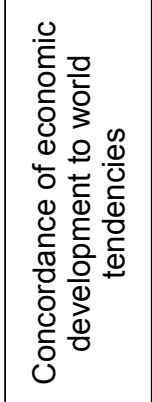 & 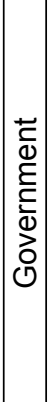 & 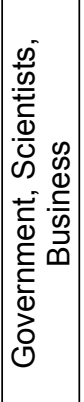 & 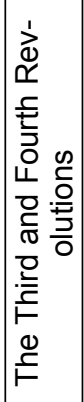 & 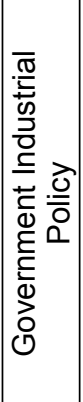 & 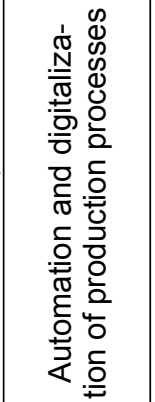 & 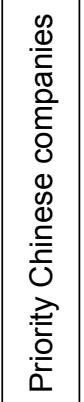 & 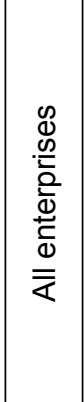 & $\begin{array}{l}\text { 음 } \\
\frac{0}{0} \\
\frac{0}{0} \\
\text { 임 } \\
\end{array}$ & ণ্ণ & $\begin{array}{l}\frac{\pi}{ \pm} \\
\frac{\pi}{0} \\
0 \\
\end{array}$ \\
\hline 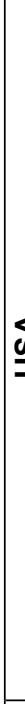 & 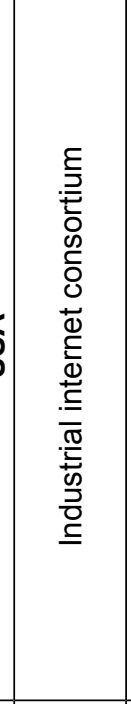 & 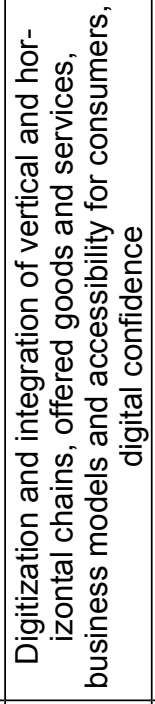 & 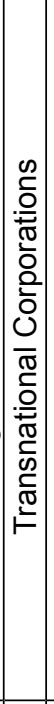 & 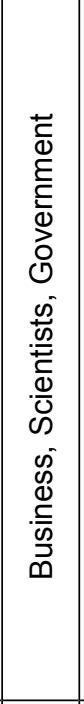 & 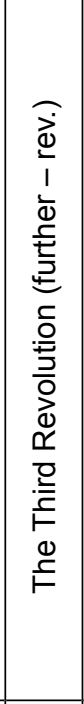 & 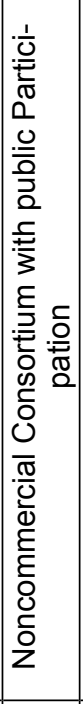 & 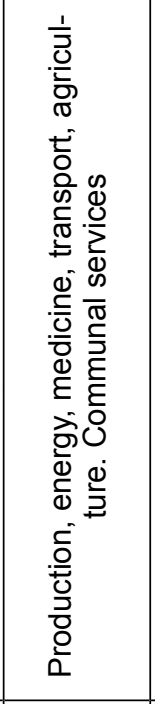 & 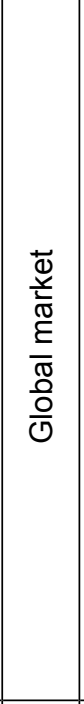 & 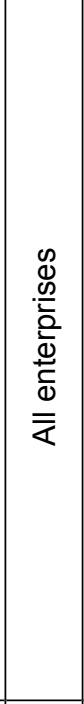 & 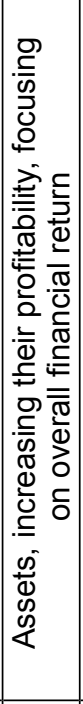 & $\begin{array}{l}\frac{\pi}{\pi} \\
\frac{\pi}{0} \\
\text { 읃 }\end{array}$ & 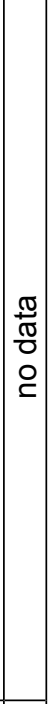 \\
\hline & 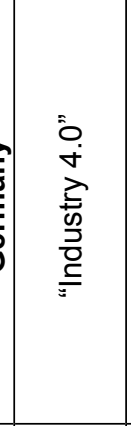 & 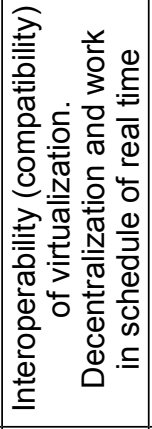 & 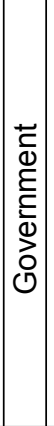 & 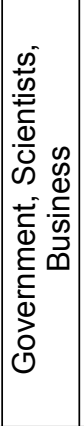 & 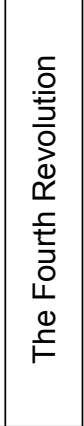 & 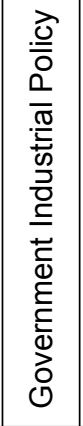 & 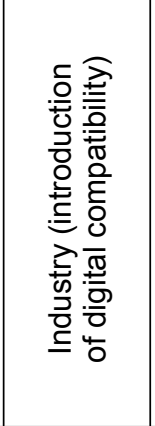 & 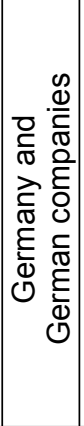 & 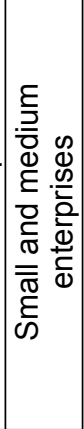 & 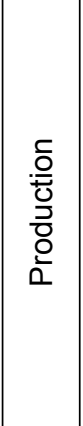 & $\stackrel{\sim}{\stackrel{N}{~}}$ & 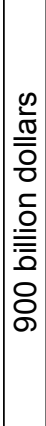 \\
\hline & 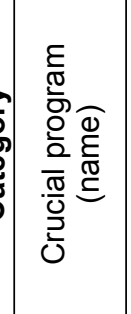 & $\begin{array}{l}\mathscr{D} \\
\mathbb{N} \\
\stackrel{D}{D} \\
\cup\end{array}$ & 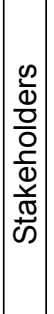 & 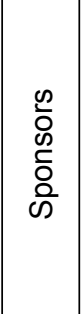 & 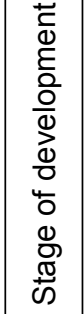 & 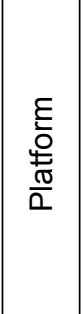 & 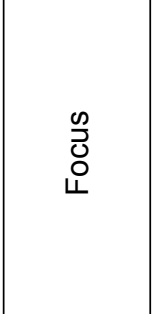 & $\begin{array}{l}\text { ते } \\
\frac{0}{\sigma} \\
\stackrel{0}{0} \\
\mathbb{d} \\
0\end{array}$ & 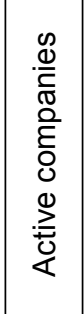 & 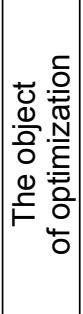 & 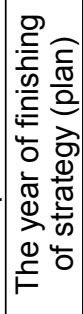 & 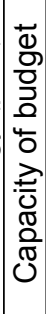 \\
\hline
\end{tabular}


compliance with the procedure of purchase and sale of financial product;

- high costs to verify the reliability of the commitments undertaken by the parties.

The main socio-economic priorities of modern education in Ukraine are determined by the conditions for the implementation of the fourth industrial revolution in the Concept «Industry 4.0» and generated by leading countries of the world whose economies are based on the domination of processes of mastering new energy resources in the world. The comparative table of the competitive advantages of particular countries in the fourth industrial revolution is given in Table 2 .

Regardless the economic progress of the last five years; the increasing the number of educated youth (Table 3), a broad aim of education and training in Europe embraces such goals as active citizenship, job skills, personal development and well-being. On the background of slow economic growth and labor shortages through demographic aging, the most pressing challenges for European states are to meet the needs of the economy and the rapidly growing unemployment among young people.

The comparative table of Poland's competitive advantages in realization the Concept Industry 4.0 matches to global trends.

In the nearest perspective, Europe will restore economic growth through increasing of productivity and the supply of highly skilled workers. And exactly reform of education and training systems have essential meaning for achieving this goal. For this purpose, the general trend in the education system was fundamentalized (related to the formation of global models of competences and monitoring of international agencies of the educational level of youth, including Ukrainian, according to international programs $[32,33,34,35,36])$ and tools, mechanisms and sources of financing. The general trend in the education system is connected with the formation of global models of competencies, monitoring of international agencies of the educational level of youth, including Ukrainian, PISA, World Economic Forum, Nonprofit Organization for the 21st Century Learning, Non-Profit International Organization «CP» - the Center for Curriculum Redesign (CCR) [37]. Accepting the results of systematization of scientific approaches and legislative norms regarding the interpretation of the concept of competence in the field of education [38], modern educational priorities are built using generally recognized classification categories within the post-industrial society [39-44]:

- Council of Europe (1996) - socio-political, multicultural, communicative, technological, cognitive;

- OECD - Interactive use of tools (language, knowledge and technology), autonomy in actions and responsibilities, interaction in heterogeneous groups (through tolerance, cooperation, group conflict resolution, etc.);

- Ukraine (2018) - the singular standard within the sphere of education has not been formed at all levels of education. Generalized: communication by the state (and by native in case of difference) and foreign languages, mathematical literacy, competence in natural sciences and technologies, information-digital competence, ability to study during life. In Ukraine, there is currently a lack of the conceptual definition of the vector of educational development. The European coun-

Table 3

Indicators of continuity of education in particular countries of the world (extract)

\begin{tabular}{|c|c|c|c|}
\hline Category & Ukraine & Germany & Poland \\
\hline $\begin{array}{l}\text { Modulus of getting the primary education in the 1st grade (2017): } \\
\% \text { of the corresponding age group of boys } \\
\% \text { of the corresponding age group of girls }\end{array}$ & $\begin{array}{l}100(2015) \\
102(2015)\end{array}$ & $\begin{array}{l}104 \\
103\end{array}$ & $\begin{array}{l}131 \\
133\end{array}$ \\
\hline $\begin{array}{l}\text { Achievements }(1999,2016) \text { : } \\
\text { Boys, } 5 \text { th grade, in } \% \text { of pupils of the } 1 \text { st grade } \\
\text { Girls, } 5 \text { th grade, in } \% \text { of pupils of the } 1 \text { st form }\end{array}$ & $\begin{array}{l}\text { no date } \\
\text { no date }\end{array}$ & $\begin{array}{l}\text { no date } \\
\text { no date }\end{array}$ & $\begin{array}{l}98 \\
99 \\
\end{array}$ \\
\hline $\begin{array}{l}\text { Achievement of the last elementary level of education (2016): } \\
\text { Boys, in } \% \text { of pupils of the } 1 \text { st grade; } \\
\text { Girls, in } \% \text { of pupils of the } 1 \text { st form }\end{array}$ & $\begin{array}{l}98 \\
98\end{array}$ & $\begin{array}{l}\text { no date } \\
\text { no date }\end{array}$ & $\begin{array}{l}98 \\
98\end{array}$ \\
\hline $\begin{array}{l}\text { Retransmitters in elementary education (2017): } \\
\text { of young people, in } \% \text { of enrolled } \\
\text { Girls, in } \% \text { of enrolled }\end{array}$ & $\begin{array}{l}0 \\
0\end{array}$ & $\begin{array}{l}0 \\
0\end{array}$ & $\begin{array}{l}1 \\
1\end{array}$ \\
\hline $\begin{array}{l}\text { Transition to secondary education (2016): } \\
\text { Men\% } \\
\text { Women,\% }\end{array}$ & $\begin{array}{l}100 \\
100\end{array}$ & $\begin{array}{l}100 \\
100\end{array}$ & $\begin{array}{c}100 \\
99\end{array}$ \\
\hline
\end{tabular}

Source: [6] 
tries, to which Ukraine seeks to meet in a short time, have identified sufficiently mobile competences for young people in education. As for the Ukrainian youth, it has low mobile competence at the "start-finish" of the educational process.

The growing role of technologies in socio-economic development makes state regulation of the subjects of generators of new technologies necessary. It is the state regulation of Ukraine that should not be static. It should take into account the complexity of the latest trends in the transfer of knowledge and technology from universities and public organizations to industry and business, support the development of small and medium-sized enterprises, initiate on its own platform the launching of business. The domination of endowment financing for domestic universities and, in general, education systems is currently unacceptable because of lowering the solvency of the country's population, employment problems, the location of educational institutions in funding sources, the lack of links, and, consequently, requests for "liquidity" Specialists and others like that. At the initiative of the Ministry of Education and Science of Ukraine, modern teachers of High Educational Establishment have been supported by the idea of academic mobility for over 10 years, which, of course, extends the range of communication and professional relationships, professional teaching skills. But against the background of quantitative growth, qualitative changes are slowed down. Otherwise, the acquisition of new competencies, with the return of teachers-scientists to the country, would contribute to a quantitative breakthrough in the educational process, which would be reflected upon the request of entrants for a particular specialty. A febrile breakthrough is not observed. There is another - outflow of youth abroad, including for studying.

Necessary framework conditions for innovation within the IHE that would meet the requirements of the time and contributed to the effective investment of new business processes at the initiative of educational institutions and graduate change generators for graduate students. For this purpose, the IHE must have equipped laboratories, business incubators, etc. as start-up sites for startups and the first business trials of large corporations. Again, in this case, there should be a feedback from the business environment with the IHE, which is interested in increasing the productivity of production processes and financial results. As long as the business is happy with the current sourc- es of labor productivity growth due to the renewal of foreign assets and state inflation policy, by that time there will be a problem at the request of university entrants.

To summarize, in the near future, with the intensification of the implementation of the fourth industrial revolution in economic life, the following directions of educational training will be sought:

- technical specialties (professions) - for the accumulation of technical knowledge, the creation of new technical units and the expansion of technical activities;

- economic - for the accumulation of technical knowledge and its improvement;

- humanitarian - for the development of technical consciousness [37].

And, in this case, we can talk about the difference in the meaning of the two categories: educational progress (like economic growth) and educational development (equivalent to the economic development described earlier).

Conclusions and suggestions. As indicated by the text of the article, the problem is polyhedral. There are several problems of increasing the financial education of citizens in a decentralized environment. These are: transformation of the educational process as a result of the natural evolution of social, intellectual, technical and technological innovations; change of the vector and priorities, competencies and norms of training of financiers; the features of decentralization in Ukraine (change the ways of managing of public finances, in particular in the field of education, the development of institutions serving finances together with capital market players, decentralization of regional development policy, and the independent financial economy of territorial communities).

However, their existence should be the basis for improving the processes of obtaining Ukrainian financial education and enhancing these results in conditions of decentralization.

In the first case, we are talking about reforming the education system, which in modern Western society has led to informationalism (the term of M. Castells) - an increase in the gap between the poor and the rich [40, 43]. M. Castells notes three fundamental "social failures" of the current information age [45]:

- internal fragmentation of the workforce into information producers and labor force, which can be replaced by robots and automatic machines. This leads to the depreciation of human values [44, p. 41]; 
- the social exclusion of a significant segment of a society that consists of individuals-specialists whose profession is unclaimed in the labor market;

- section of the market logic of global network flows of capital and human worker experience.

Agreeing that the problem of personal professional development in Ukraine and personal development of a professional still has no adequate legislative, socio-pedagogical and scientific-theoretical solution [3], the conceptual design of organizational models of psychological and pedagogical support for the professional development of personality in the field of socio-occupational professions is not appropriate for the absence of active labor market models. In addition, the formalization of creativity as a process and result is a false way to mastering the "technology of anthropo-social development of individual life" of a person.

\section{References:}

1. Фінансова грамотність, обізнаність та інклюзія в Україні: Звіт про дослідження. Додатковий проект IP-FSS в Україні. Проект регіонального економічного розвитку. 2017. 69 с. URL: https://bank.gov.ua/doccatalog/document? id=83136332 (дата звернення: 20.03.2019).

2. 78 громад чекають на перші вибори, а 96 районів усе ще без ОТГ: Мінрегіон оприлюднив оновлений моніторинг децентралізації. URL: https://decentralization.gov.ua/news/10749?f bclid=IwAR1 N8agzDK3t7MA23EV9TBbbVnu Bj_nQkmNoEJ3JOkOkVIX3wOCM2ofQDt8 (дата звернення: 20.03.2019).

3. Закревський В.Е. Розвиток суперпрофесіоналів: антропосоціальний та соціально-педагогічний виміри. Наука i освіта. 2013. № 1-2. С. 30-35.

4. Шваб К. Четвертая промышленная революция. Москва : Эксмо, 2016. 208 с.

5. Bell D. (1973). The Coming of Post-Industrial Society: A Venture in Social Forecasting. Basic Books, New York. USA. P. 507.

6. World Development Indicators: Education efficiency. URL: http://wdi.worldbank.org/table/ 2.9 (дата звернення: 20.03.2019).

7. Фукуяма Ф. Доверие: социальные добродетели и путь к процветанию ; пер. с англ. Москва : ООО «Издательство АСТ » З ЗАО НПП «Ермак», 2004. $730 \mathrm{c}$.

8. Fukuyama F. (2000). Social capital and civil society. Working paper 00/74. Washington, DC : International Monetary Fund. P. 18.

9. Helliwell J., Putnam R. Education and Social Capital. URL: http://college.holycross.edu/eej/ Volume33/V33N1P1_19.pdf (дата звернення: 20.03.2019).
10.Певзнер М.Н., Петряков П.А. Вузы Германии как гетерогенные организации: как управлять многообразием? Вестник Новгородского государственного университета. 2017. № 4 (102). С. 92-96.

11.Про затвердження Ліцензійних умов провадження освітньої діяльності : постанова Кабінету Міністрів України від 30.12.2015 р. № 1187. URL: https://zakon.rada.gov.ua/laws/show/11872015-\%D0\%BF (дата звернення: 20.03.2019).

12.Аналітична доповідь до щорічного Послання Президента України до Верховної Ради України «Про внутрішнє та зовнішнє становище України в 2018 році» (01.12.2018). URL: http://niss.gov.ua/ doslidzhennya/naukovi-vidannya/poslannyaprezidenta-ukraini/analitichna-dopovid-doschorichnogo (дата звернення: 20.03.2019).

13.Байденко В.И. Болонский процесс: структурная реформа высшего образования Европы : научное издание. Москва : Исследовательский центр проблем качества подготовки специалистов, 2002. 123 с. С. 13-20.

14.Kurt De Wit, Jef C. Verhoeven, Dirk Heerwegh. Do ICT Competences Support Educational Attainment at University? Journal of Information Technology Education: Research. 2012. Volume 11. URL: https://www.researchgate.net/publication/216845554 (дата звернення: 20.03.2019).

15.Гумбольдт В. Про внутрішню та зовнішню організацію вищих навчальних закладів у Берліні. ІӘея Університету: Антологія ; упор. М. Зубрицька, Н. Балик, З. Рибчинська;відп. ред. М. Зубрицька. Львів : Літопис, 2002. С. 25-33.

16.Гербст М., Герчинський Я. Децентралізація освіти у Польші: досвід 25 років ; Інститут освітніх досліджень. Варшава, 2015. 24 с.

17.Poland Higher Education System. The European Education Directory. URL: http://www.euroeducation.net/prof/polaco.htm.

18.Досвід Німеччини. Звіти Групи. Офіційна сmорінка Б. Гаврилишина. URL: http://bhfoundation. com.ua/news_935.html

19.Новіков В.М. Розвиток професійно-технічної освіти в умовах децентралізації системи управління в Україні. Демографія та соціальна економіка. 2017. № 2 (30). С. 126-137.

20.Management mechanisms and financing of higher education in Germany. URL: https://www.oecdilibrary.org/education/management-mechanismsand-financing-of-higher-education-in-germany_ hemp-v15-art6-en

21. Five Reasons to Study Business in Germany. URL: https://www.topmba.com/where-to-study/europe/ germany/five-reasons-study-business-germany.

22. Юрчук Л. Тенденції децентралізації управління освітою в Україні. Вісник Національної академії державного управління при Президентові України. 2009. Вип. 4. С. 276-283. 
23.Directorate for Financial and Enterprise Affairs. Recommendation on Principles and Good Practices for Financial Education and Awareness. RECOMMENDATION OF THE COUNCIL, 2005. URL: http://www.oecd.org/finance/financialeducation/35108560.pdf

24.Федоркова Т. Децентрализация в Польше. 25 лет спустя. URL: https://www.mediaport.ua/ decentralizaciya-v-polshe-25-let-spustya

25.Юрій С.І., Кізима Т.О. Фінансова грамотність населення у діалектиці сучасних освітніх тенденцій. Фінанси України. 2012. № 2. C. $16-25$.

26. Овчинников М. Обзор международной практики реализации стратегий и программ в области финансовой грамотности. Москва : Наука, 2008. $215 \mathrm{c}$.

27.Доклад о человеческом развитии 2016. Человеческое развитие для всех и каждого. URL: http://hdr.undp.org/sites/default/files/hdr_2016_ report_russian_web.pdf (дата звернення: 20.03.2019).

28.Плакиткин Ю.А., Плакиткина Л.С. Мировой инновационный проект «Индустрия 4.0» возможности применения в угольно отрасли России. Уголь. 2017. № 10. С. 44-50.

29.Юдина М.А. Индустрия 4.0: перспективы и вызовы для общества. Государственное управление. Электронный вестник. 2017. Вып. № 60. С. 197-215.

30.China Manufacturing 2025: Putting Industrial Policy Ahead of Market Forces. URL: http://www.europeanchamber.com.cn/en/ china-manufacturing-2025 (дата звернення: 20.03.2019).

31.Webster F. (1995). Theories of the Information Society. 1st ed. Routledge, Oxoford. United Kingdom. P. 314.

32.Center for Curriculum Redesign. The official Web-site. URL: http://curriculumredesign.org/ (дата звернення: 20.03.2019).

33. Lee Kuan Yew. (2000). From Third World to First: 1965-2000: Memoirs of Lee Kuan Yew. The Singapore Story. Harper. Vol. 2. P. 752.
34.New Vision for Education Unlocking the Potential of Technology. World Economic Forum. URL: http://www3.weforum.org/ docs/WEFUSA NewVisionforEducation_Report2015.pdf (дата звернення: 20.03.2019).

35.Partnership for 21st Century Learning. The official Web-site. URL: http://www.p21.org/ (дата звернення: 20.03.2019).

36.PISA 2015 Results. URL: http://www.oecd.org/ pisa/ (дата звернення: 20.03.2019).

37.Ясинська Н.А. Фінансове господарство українців: формат довіри : монографрія. Миколаїв : Іліон, 2018. 379 с.

38.Компетентнісний підхід у вищій освіті: світовий досвід / Л. Антонюк та ін. Київ : КНЕУ, 2016. 61 с.

39.Офріційний сайт OECP. URL: http://www.oecd. org/ (дата звернення: 20.03.2019).

40.Про вищу освіту : Закон України від 01.07.2014 p. №1556-VII. URL: http://zakon3.rada.gov.ua/laws/ show/1556-18 (дата звернення: 20.03.2019).

41.Про затвердження Державного стандарту базової і повної загальної середньої освіти : постанова Кабінету Міністрів України від 23.11.2011 р. № 1392. URL: http://zakon3.rada.gov.ua/laws/show/1392-2011\%D0\%BF (дата звернення: 20.03.2019).

42.Про затвердження Державного стандарту початкової загальної освіти : постанова Кабінету Міністрів України від 20.04.2011 р. № 462. URL: http://zakon3.rada.gov.ua/laws/show/462-2011\%D0\%BF (дата звернення: 20.03.2019).

43.Проект Стратегії реформування вищої освіти в Україні до 2020 року URL: http://old.mon.gov. ua/ua/pr-viddil/1312/1390288033/1415795124/ (дата звернення: 20.03.2019).

44.Education and Training: Supporting education and training in Europe and beyond. The official Web-site of The European Commission. URL: https://ec.europa.eu/education/policy/school/ competences_en (дата звернення: 20.03.2019).

45.Кастельс М. Информационная эпоха: экономика, общество и культура ; пер. с англ. под науч. ред. О.И. Шкаратана. Москва : ГУ ВШЭ, 2000. 606 c. 


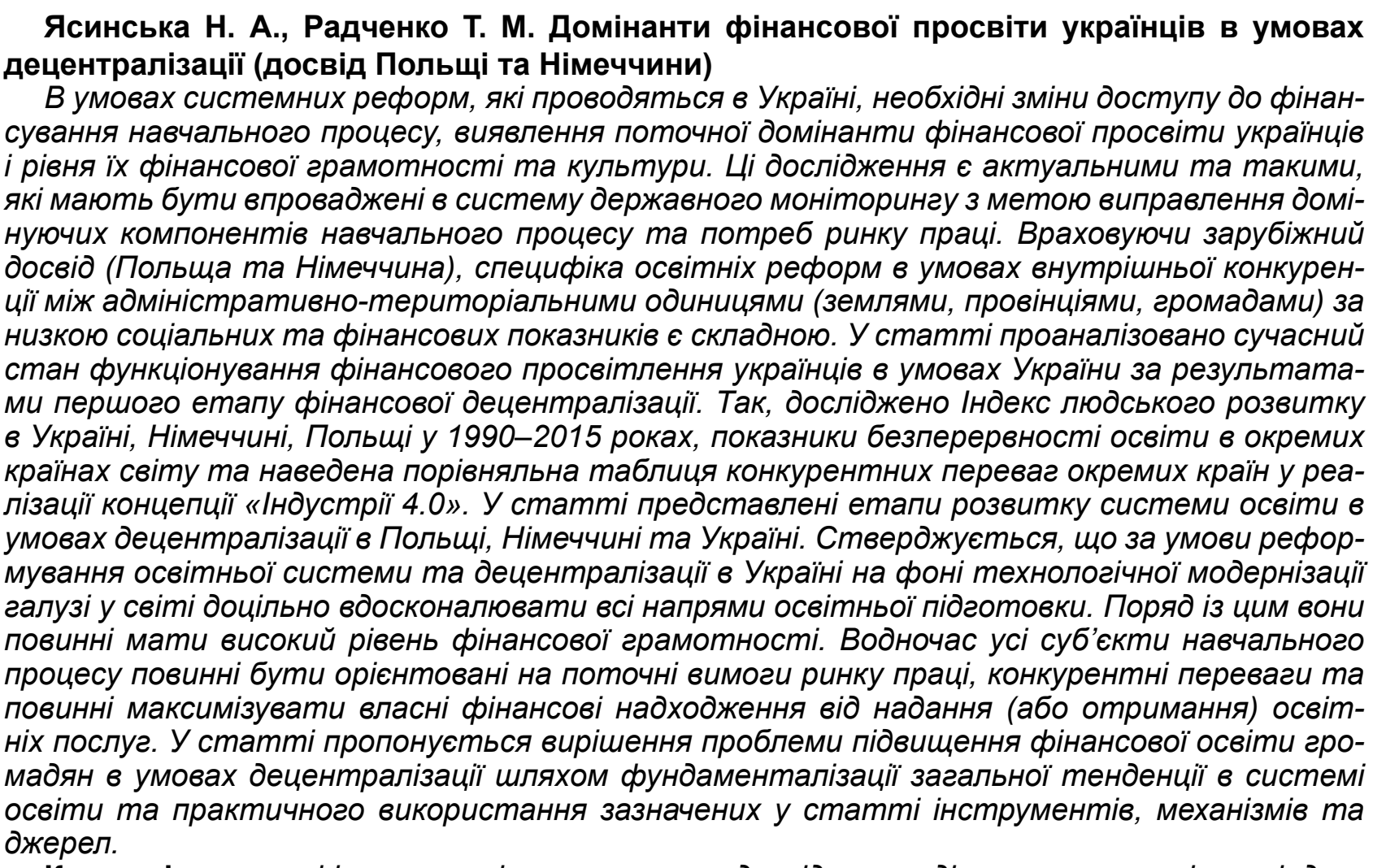

Ключові слова: фрінанси, освіта, культура, досвід, розподіл, компетентність, індекс людського розвитку. 